\title{
UDZIAL PRZEDSIĘBIORCÓW W PODEJMOWANIU DECYZJI PUBLICZNYCH W SFERZE GOSPODARCZEJ NA POZIOMIE LOKALNYM
}

\section{WPROWADZENIE}

Jednym z najważniejszych osiagnięć transformacji systemowej w Polsce jest rozwój samorządności. Podejmując reformy decentralizacyjne, zdano sobie sprawę, że budowa nadmiernie centralistycznego modelu administracji nie służy państwu i może mieć charakter dysfunkcjonalny. Słusznie uznano, że brak partycypacji społecznej w życiu publicznym oraz alienacja elit władzy stanowią zarzewie kryzysu struktur państwowych ${ }^{1}$.

Z perspektywy lat widać wyraźnie, że szeroka decentralizacja sfery władztwa publicznego doprowadziła do realnego upodmiotowienia polskiego społeczeństwa. Kluczową rolę w tym procesie odgrywa rzecz jasna samorząd terytorialny, który już od ćwierćwiecza stanowi ważny element systemu politycznego Polski. Warto w tym miejscu przypomnieć, że 8 marca 1990 r. została uchwalona ustawa o samorządzie terytorialnym (obecnie gminnym), która doprowadziła do restytucji władzy lokalnej w Polsce, a zarazem stanowiła pierwszy krok do dalszych reform samorządowych zwieńczonych ustanowieniem samorządu powiatowego i wojewódzkiego. W efekcie ich wdrażania od 1 stycznia 1999 r. wprowadzono zasadniczy trójstopniowy podział terytorialny państwa, którego jednostkami stały się gminy, powiaty i województwa. Tak dalece posunięta decentralizacja wykreowała samorząd na wszystkich szczeblach zarządzania². Jego strukturę w Polsce można od strony formalnoprawnej uznać za spójną. Samorządy gminne, powiatowe i wojewódzkie postrzegane sa, mimo pewnych zastrzeżeń dotyczących podziału kompetencji oraz sposobu generowania przychodów budżetowych, jako ważne jednostki administracji publicznej.

System trójszczeblowego samorządu terytorialnego jest zatem efektem wieloletniego procesu reform. Widać jednak wyraźnie, że sukcesywnie wyczerpuje się statyczna formuła prowadzenia polityki lokalnej. Wydaje się, że należy coraz intensywniej włączać inne - zewnętrzne podmioty do struktur zarządczych po to, aby usprawnić i zracjonalizować proces podejmowania de-

\footnotetext{
${ }^{1}$ P. Antkowiak, Samorzad zawodowy w Polsce, Warszawa-Poznań 2012, s. 7.

${ }^{2}$ R. Kmieciak, Samorzad zawodowy i gospodarczy w Polsce po 1989 roku, „Przegląd Politologiczny" 2011, nr 4, s. 49.
} 
cyzji publicznych, co bezpośrednio przekłada się na rozwój gospodarczy danego obszaru. Odpowiedzią na takie zapotrzebowanie jest koncepcja zarządzania publicznego, natomiast grupa społeczna, która w przekonaniu autorów powinna mieć wpływ na podejmowanie decyzji publicznych w sferze gospodarczej, sa bez watpienia przedsiębiorcy ${ }^{3}$.

W tradycyjnym rozumieniu, podział ról w życiu społecznym jest jasno określony. Administracja samorządowa ze względu na swoja pozycję ustrojowa, posiadane kompetencje oraz możliwości rozwojowe sprawuje władzę na danym terytorium i wykonuje zadania publiczne. Z kolei przedsiębiorcy, co należy uznać za rzecz naturalna, dążą do wypracowania zysku. Dysponują oni odpowiednim kapitałem pieniężnym, a ich doświadczenia gospodarcze stanowia nieocenioną wartość. Dobrze jeśli przy prowadzeniu swojej działalności kierują się zasadami etyki biznesu4.

\section{POŻĄDANY KIERUNEK ZMIAN MODELU SAMORZĄDU GOSPODARCZEGO W POLSCE}

Samorząd nie jest pojęciem jednowymiarowym odnoszącym się wyłącznie do stosunków terytorialnych. Bardzo ważną rolę w systemie reprezentowania interesów określonych grup obywateli odgrywa samorząd specjalny, który wyodrębnia się według innych kryteriów. W jego ramach wyróżnić możemy np. związki ekonomiczne, których zadaniem jest rzecznictwo interesów środowiska gospodarczego. Jak się zatem wydaje, na samorząd należy obecnie spojrzeć z nieco innej perspektywy, nie tylko przez pryzmat społeczności zorganizowanych terytorialnie, ale również z punktu widzenia środowiska przedsiębiorców, a więc w kategoriach governance. Asymetria w badaniach nad systemem wieloszczeblowego zarządzania w Polsce i innych państwach skłania do pogłębionej refleksji w tym zakresie. Jest to szczególnie istotne w kontekście poszukiwania nowych i efektywnych form współpracy na szczeblu lokalnym pomiędzy jednostkami samorządu terytorialnego a środowiskiem przedsiębiorców.

Odwołując się do koncepcji governance, należy przypomnieć, że jest to funkcja zarządzania złożonymi społecznościami poprzez koordynowanie działań podmiotów należących do różnych sektorów. Definicję tę można odnieść także do public governance. Jak zauważa Hubert Izdebski, takie publiczne zarządzanie, które nie musi należeć wyłącznie do władzy publicznej, łączy się

${ }^{3}$ P. Antkowiak, Teoretyczne i praktyczne aspekty tworzenia partnerstwa lokalnego jako nowej metody zarzadzania publicznego, w: idem (red.), Subregionalny Katalog Zmian Gospodarczych i Mechanizmów Zaradczych. Region pótnocno-wschodniej Wielkopolski, Poznań 2013, s. 15-32; A. Kołomycew, Partnerstwa międzysektorowe na poziomie lokalnym. Uwarunkowania rozwoju Lokalnych Grup Działania w województwie podkarpackim, w: P. Antkowiak (red.), Polska i Europa wobec wyzwań wspótczesnego świata. Doświadczenia i perspektywy rozwoju samorzqdu terytorialnego $i$ zawodowego, Toruń 2014, s. 82-103.

${ }^{4}$ D. Polakowski, Strategia rozwiazywania problemów społecznych na poziomie lokalnym w oparciu o partycypacje spotecznq, w: A. Frączkiewicz-Wronka (red.), Partnerstwo lokalne jako strategia rozwiazywania problemów spotecznych, Katowice 2012, s. 143-166. 
z odchodzeniem od traktowania obywateli tylko jako wyborców, wolontariuszy czy konsumentów usług publicznych i z przejściem do upatrywania w nich interesariuszy oraz - dzięki temu, że daje się im do rozwiązania problemy, które ich dotyczą - współdecydentów i współkreatorów wspólnego dobra ${ }^{5}$.

Dzisiaj rolą władz publicznych jest zatem w mniejszym stopniu kreowanie polityki, a o wiele bardziej moderowanie różnych aspektów polityki publicznej. Administracja publiczna ujmowana w kategoriach governance, w tym jej tak istotny element, jakim jest samorząd, stanowi część mechanizmów życia społeczeństwa, uczestnicząca w rozwiązywaniu problemów zbiorowych przy udziale zainteresowanych jednostek i grup lub ich przedstawicieli ${ }^{6}$.

W tym kontekście należy wskazać na zmodyfikowaną rolę samorządu terytorialnego w systemie wieloszczeblowego zarządzania. Kluczowe jest scharakteryzowanie nowych kierunków współpracy samorządu terytorialnego $\mathrm{z}$ otoczeniem gospodarczym $\mathrm{w}$ ramach koncepcji governance. Wzmacnianie tego typu współdziałania może mieć podstawowe znaczenie dla rozwoju gospodarczego w wymiarze lokalnym. Ważne jest zatem pytanie dotyczace form współpracy samorządu terytorialnego ze środowiskiem społecznym przedsiębiorców. Jest to niezwykle istotne dla określenia poziomu partycypacji świata biznesu w funkcjonowaniu władzy publicznej, a jednocześnie nawiązuje do kluczowej dla prezentowanego materiału kwestii, a mianowicie szansy wprowadzenia na szczeblu lokalnym systemu wielopoziomowego zarządzania, opartego na wzajemnym zaufaniu.

W tym miejscu należy jednak zauważyć, że najpoważniejszym problemem $\mathrm{w}$ relacjach pomiędzy samorządem terytorialnym a środowiskiem przedsiębiorców jest słaba komunikacja, wynikająca z asymetrycznych stosunków instytucjonalnych i prawnych. Nie ma w praktyce sformalizowanej płaszczyzny współpracy samorządu i biznesu. Środowisku gospodarczemu towarzyszy poczucie instrumentalnego traktowania przez samorząd, z kolei władze lokalne i regionalne narzekają na ograniczone możliwości nawiązania dialogu społecznego z przedsiębiorcami. Taka sytuacja zagraża realizacji koncepcji wielopoziomowego zarządzania, akcentującej coraz bardziej złożoną sieć powiązań funkcjonalnych pomiędzy instytucjami różnych szczebli i sektorów. Jak się zatem wydaje, niezbędne jest wyłonienie spójnej organizacji przedsiębiorców, która byłaby zdolna do prowadzenia działalności doradczej i eksperckiej względem samorządu terytorialnego.

Optymalnym rozwiązaniem tego problemu jest utworzenie samorządu gospodarczego, który powinien stać się instytucją reprezentatywną dla własnego środowiska. Rozbudowywanie bazy członkowskiej przy zachowaniu obecnie stosowanych metod nie doprowadzi do sukcesu. Alternatywa jest ustawowe wykreowanie organizacji samorządu gospodarczego, wzorem ustaw decentralizacyjnych tworzacych samorząd terytorialny. Powołany w ten sposób samorząd gospodarczy stanie się partnerem władz administracyjnych, w tym struk-

${ }^{5}$ H. Izdebski, Samorzad terytorialny. Podstawy ustroju i działalności, Warszawa 2009, s. 33.

${ }^{6}$ R. Kmieciak, P. Antkowiak, M. Balcerek, Wspótpraca środowiska gospodarczego z samorzadem terytorialnym w aglomeracji poznańskiej, Poznań 2012, s. 11. 
tur samorządu różnych szczebli, stanie się w istocie rzeczy elementem sfery władz publicznych w Polsce.

Organizacjami tak rozumianego samorządu gospodarczego sa przede wszystkim izby przemysłowo-handlowe, rzemieślnicze i rolnicze. Mają one określony przez ustawę zakres zadań, które wykonywane są samodzielnie i niezawiśle od innych podmiotów administracji publicznej. Zakres tych zadań jest miara decentralizacji administracji państwa w sferze gospodarczej; jest też wyrazem zaufania państwa do obligatoryjnie zorganizowanego w izbach czynnika obywatelskiego, a także przekonania, że jest on w sprawach gospodarki lokalnej i regionalnej bardziej kompetentny od urzędników administracji rządowej. Dzięki samorządowi gospodarczemu społeczność przedsiębiorców ze zbiorowości indywidualnych, rozproszonych jednostek staje się zorganizowaną zbiorowością publicznoprawną, czyli wspólnotą samorządową wyposażoną we władztwo administracyjne.

Kryterium samorządowości izb przemysłowo-handlowych powinno być zatem wykonywanie przez nie określonej sfery władztwa administracyjnego. Stosując to rozróżnienie, należy zachować daleko idąca powściagliwość przy utożsamianiu stowarzyszeń, reprezentujących wolę najczęściej wąskiej grupy przedsiębiorców, z samorządem gospodarczym. Pamiętajmy, że samorząd gospodarczy podejmuje inicjatywy, które na stałe wpisane są w jego obszar działania i nie tylko przyczynia się do poprawy sytuacji indywidualnych podmiotów gospodarczych, lecz także realizuje cele rozwoju lokalnego i regionalnego, a także ma wpływ na politykę gospodarczą państwa. Wyrazem tej działalności jest dbałość izb gospodarczych o ład rynkowy, o rozwój przedsiębiorczości, systemu kształcenia i szkoleń, wsparcie dla innowacyjności i zarządzanie usługami publicznymi.

Analiza ustroju i zadań izb tego typu pozwala na postawienie tezy, że ich działania mają charakter służby publicznej, wykonywanej w formach zdecentralizowanych przy udziale czynnika obywatelskiego. Izby przemysłowo-handlowe, jako korporacje publicznoprawne o obligatoryjnym członkostwie i władztwie administracyjnym, są zatem instytucjami samorządu gospodarczego w znaczeniu teorii prawa administracyjnego; legitymizuja demokratyczny i obywatelski charakter państwa.

Działajace w Polsce izby przemysłowo-handlowe pozostają niestety zwiąkami prywatnoprawnymi, co nie stawia ich na płaszczyźnie partnerskich relacji w stosunku do administracji publicznej. W konsekwencji wpływ przedsiębiorców na politykę gospodarczą państwa można uznać za symboliczny. W jakim kierunku powinno zatem zmierzać funkcjonowanie samorządu gospodarczego? Przede wszystkim powinien on się stać się instytucja reprezentatywną dla własnego środowiska. Rozbudowywanie bazy członkowskiej przy zachowaniu obecnie stosowanych metod nie doprowadzi do sukcesu. Alternatywa jest ustawowe wykreowanie instytucji samorządu gospodarczego, wzorem ustaw decentralizacyjnych tworzących samorząd terytorialny, lub też oparcie go na sprawdzonym modelu samorządu zawodowego. Nie ulega wątpliwości, że znacznie większe możliwości otwierają się przed organizacjami powszechnego samorządu gospodarczego. 
W zakresie szczegółowych kompetencji tak zorganizowanych izb przemysłowo-handlowych wymienić należy:

- reprezentowanie interesów grupowych wobec państwa;

- prawo opiniowania i współkształtowania projektów aktów prawnych dotyczacych sfery społeczno-gospodarczej;

- poprawę bezpieczeństwa obrotu gospodarczego i ochrony przed nieuczciwą konkurencją przez wdrażanie i respektowanie standardów etycznych;

- zbieranie i transferowanie informacji gospodarczych do przedsiębiorców;

- wyrażanie opinii o projektach zarządzeń i uchwał władz samorządu terytorialnego oraz udział $\mathrm{w}$ ich opracowywaniu, a także składanie własnych wniosków w zakresie np. zagospodarowania przestrzennego, rozwoju dróg i komunikacji, podatków, inwestycji komunalnych itp.;

- zakładanie, prowadzenie i popieranie we współpracy z władzami oświatowymi szkół zawodowych i dokształcających;

- prowadzenie rejestru handlowego (izby powinny dysponować wykazem osób i jednostek organizacyjnych prowadzących działalność gospodarczą wraz z danymi dotyczącymi ich siedziby i przedmiotu przedsiębiorstwa zgłoszonych w rejonie izby) - dane pozyskane od wojewódzkich urzędów statystycznych według numeracji REGON, od urzędów skarbowych według aktualnych zgłoszeń obowiązku podatkowego - VAT, od gmin według zgłoszeń do ewidencji. Włączone w strukturę administracji poublicznej izby przemysłowo-handlowej maja ponadto do spełnienia rolę edukacyjna w zakresie inwestowania w obszar gospodarki opartej na wiedzy, ale też powinny się skoncentrować na tworzeniu własnych funduszy inwestujacych np. w wysoko rozwinięte technologie, finansowaniu działalności parków naukowo-technologicznych oraz inkubatorów przedsiębiorczości. W Polsce widoczny jest brak stałej współpracy izb przemysłowo-handlowych ze szkołami wyższymi i placówkami badawczymi, chociażby w celu stałego dostępu przedsiębiorców do nowoczesnych rozwiązań z zakresu ekonomii, zarządzania i technologii, czy wspólnego prowadzenia projektów badawczo-rozwojowych.

Kolejnym ważnym zadaniem izb przemysłowo-handlowych powinna być pomoc dotycząca podejmowania współpracy przedsiębiorstw w obszarze innowacyjności, a także jej koordynacja. Współpraca z tego zakresu może przybierać różne formy. Jedną z nich jest tzw. sieć przedsiębiorstw, którą tworzy grupa podmiotów gospodarczych zorganizowanych wokół wspólnych działań, np. produktu, rozwiązania technologicznego ${ }^{7}$.

Izby przemysłowo-handlowe mogą także wspierać przedsiębiorców w nawiązywaniu innej formy kooperacji, a mianowicie tworzenia tzw. aliansów strategicznych. Są to związki przedsiębiorstw oparte na określonych porozumieniach, które realizują wspólne cele, zachowując jednocześnie niezależność. Szczególne znaczenie mają alianse technologiczne, których zadaniem jest rozwój i transfer wiedzy.

Izby przemysłowo-handlowe jako instytucje administracji publicznej, wyposażone we władztwo administracyjne, odpowiednie środki materialne i finanso-

${ }^{7}$ A. Sudolska, Stan i potrzeba wspótpracy przedsiębiorstw w Polsce, w: W. Popławski, A. Sudolska (red.), Wspótpraca przedsiębiorstw w Polsce $w$ procesie budowania ich potencjatu innowacyjnego, Toruń 2008 , s. 107. 
we powinny mieć zatem istotny wpływ na pomoc, doradztwo w wykorzystaniu zarówno czynników zewnętrznych, jak i wewnętrznych przedsiębiorstwa, być siłą napędową podejmowanej aktywności innowacyjnej ${ }^{8}$. Niestety w obecnym stanie prawnym, działając jako stowarzyszenia, izby przemysłowo-handlowe nie maja szansy zaistnieć $\mathrm{w}$ sferze publicznej. Trudno się bowiem spodziewać, aby rząd i samorząd terytorialny dzieliły się wpływami z dobrowolnymi związkami osób, które - co należy otwarcie przyznać - nie mają mandatu do reprezentowania wszystkich przedsiębiorców z danego obszaru. W rezultacie głosy środowisk gospodarczych sa rozproszone, a politycy i działacze samorządu terytorialnego nie widzą potrzeby czynienia istotnych koncesji na rzecz słabo zorganizowanych grup przedsiębiorców.

Wszystko to skłania do zastanowienia się nad przyszłością relacji pomiędzy środowiskiem gospodarczym a samorządem terytorialnym. Kluczowa jest w tym kontekście kwestia wpływu organizacji przedsiębiorców na działania władz samorządu terytorialnego prowadzone w sferze społeczno-gospodarczej. Dla przykładu w Wielkopolsce działa wiele organizacji zajmujacych się formalnie rzecznictwem interesów podmiotów gospodarczych. Możemy tu wymienić takie struktury, jak: Wielkopolska Izba Rzemieślnicza, Wielkopolska Izba Przemysłowo-Handlowa, Wielkopolski Zwiazek Pracodawców, Wielkopolski Klub Kapitału oraz Loża Wielkopolska Business Centre Club. Do tego dochodzą organizacje majace branżowy charakter, jak np.: Wielkopolska Izba Budownictwa, Wielkopolska Izba Turystyczna, Polska Izba Gospodarcza Importerów, Eksporterów i Kooperacji czy Wielkopolskie Zrzeszenie Handlu i Usług.

Nie ulega zatem wątpliwości, że wielkopolscy przedsiębiorcy mają możliwość zrzeszania się $\mathrm{w}$ organizacjach stawiających sobie za cel reprezentowanie ich interesów. Nawiązując do koncepcji zarządzania lokalnego, warto się jednak zastanowić nad reprezentatywnością tego typu struktur oraz ich pozycją w systemie governance, chociaż trudno o pozytywne konkluzje w tych kwestiach. W przypadku wszystkich wymienionych organizacji, z wyjątkiem Wielkopolskiej Izby Rzemieślniczej, widoczne jest niewielkie zainteresowanie członkostwem ze strony przedsiębiorców. Wynika to z relatywnie słabej pozycji ustrojowej wymienionych organizacji, będącej konsekwencją ich prywatnoprawnego charakteru. Z kolei brak tego typu struktur w sferze instytucji publicznych jest, jak się wydaje, głównym powodem ich marginalizowania przez władze samorządowe, które nie widzą potrzeby i możliwości przekazywania kompetencji administracyjnych na rzecz rozproszonego środowiska gospodarczego. Wynikająca z tego słabość strukturalna i programowa organizacji biznesowych wydaje się główną przeszkodą na drodze do stworzenia efektywnego systemu wielopoziomowego zarządzania, który mógłby zniwelować zbyt asymetryczne obecnie relacje pomiędzy samorządem terytorialnym i słabą reprezentacją przedsiębiorców ${ }^{9}$. W tym miejscu pojawia się jednak pytanie dotyczące zainteresowania takimi rozwiązaniami ze strony różnych grup gospodarczych. Doświadczenia ostatniego ćwierćwiecza nie napawaja

${ }^{8} \mathrm{~K}$. Walkowiak, Działania izb przemysłowo-handlowych na rzecz rozwoju innowacyjności polskich przedsiębiorstw, „Przegląd Politologiczny” 2011, nr 4, s. 77.

${ }^{9}$ Zob. R. Kmieciak, P. Antkowiak, M. Balcerek, op. cit., s. 30-38. 
nadmiernym optymizmem. Związane jest to $\mathrm{z}$ niskim poziomem świadomości i kultury samorządowej elit gospodarczych, co w pewnym stopniu usprawiedliwia nieobecność samorządu gospodarczego w Polsce przez pół wieku. W tym czasie zlikwidowana została niemal w całości społeczność polskich przedsiębiorców. Zniknęły wielopokoleniowe rody przemysłowców, kupców, bankowców i rzemieślników - chluba polskiego mieszczaństwa i najbardziej motoryczna siła rozwoju społeczno-gospodarczego kraju. W konsekwencji powstała widoczna próżnia, której nie udało się wypełnić działaniami na rzecz dobra wspólnego.

\section{OPINIA WIELKOPOLSKICH PRZEDSIĘBIORCÓW NA TEMAT ORGANIZACJI ZRZESZAJĄCYCH PRZEDSIĘBIORCÓW ORAZ SAMORZĄDU GOSPODARCZEGO}

W dyskusji na temat zasadności powołania w Polsce powszechnego samorządu gospodarczego należy uwzględnić głos osób najbardziej zainteresowanych istnieniem tego rodzaju instytucji, a mianowicie przedsiębiorców. Z tego powodu zespół autorów opracował formularz ankiety, której zasadniczym celem było zbadanie opinii wielkopolskich przedsiębiorców na temat organizacji zrzeszajacych przedsiębiorców oraz samorządu gospodarczego ${ }^{10}$. Podczas badań ankietowych starano się uzyskać odpowiedź na pytanie: „Czy samorząd gospodarczy jest potrzebny, a jeśli tak - to jaka powinna być jego rola i zasady funkcjonowania?".

Badanie zostało przeprowadzone drogą elektroniczna przez firmę F5 Konsulting, która w sposób profesjonalny i kompleksowy opracowała jego wyniki ${ }^{11}$. Należy również dodać, że cały projekt został zrealizowany pod patronatem Wielkopolskiej Izby Przemysłowo-Handlowej, a jego wyniki zaprezentowano na V Forum Gospodarczym Aglomeracji Poznańskiej ${ }^{12}$.

Prośbę o wypełnienie elektronicznego formularza ankiety wysłano do ok. 700 przedsiębiorców z Wielkopolski, w tym do ok. 500 osób, które uczestniczyły w poprzednich edycjach Forum Gospodarczego Aglomeracji Poznańskiej, a następnie do 183 członków Wielkopolskiej Izby Przemysłowo-Handlowej. Ponadto firma F5 Konsulting rozesłała ankietę do firm, z którymi na stałe współpracuje. Otrzymano 54 kompletnie wypełnione ankiety, które poddano dalszej analizie, co oznacza, że ankietę wypełniło zaledwie 7,71\% spośród firm, do których została ona skierowana. Świadczy to jednoznacznie o niewielkim

10 Przedstawione wyniki badań zostały przygotowane przez zespół badaczy w składzie: prof. dr hab. Robert Kmieciak, dr Paweł Antkowiak, mgr Marta Balcerek z Zakładu Badań Władzy Lokalnej i Samorządu Wydziału Nauk Politycznych i Dziennikarstwa Uniwersytetu im. Adama Mickiewicza w Poznaniu. Zostały one opublikowane w poszerzonej formie w pracy Wspótpraca środowiska gospodarczego z samorzadem terytorialnym w aglomeracji poznańskiej, Poznań 2012. Praca została sfinansowana ze środków Centrum Badań Metropolitalnych UAM w Poznaniu.

11 Zob. http://www.f5.pl (dostęp: 19.05.14).

12 Zob. http://www.forumgospodarcze.com (dostęp: 19.05.14). 
zainteresowaniu respondentów omawianą kwestia, co również należy uznać za bardzo istotną informację $e^{13}$.

Badanie przeprowadzone zostało metodą sondażowa, przy wykorzystaniu technik ankietowania. Narzędziem natomiast był elektroniczny i anonimowy kwestionariusz ankiety.

Zanim przedstawione zostaną wyniki przeprowadzonego badania, należy scharakteryzować badaną grupę respondentów. Jak już wskazano, w badaniu wzięło udział 54 przedsiębiorców, którzy kompletnie wypełnili ankietę. Szczegółową charakterystykę badanej grupy przedsiębiorców zawiera tabela 1.

\section{Tabela 1}

Charakterystyka badanej grupy przedsiębiorców

\begin{tabular}{|c|c|c|c|c|}
\hline \multicolumn{5}{|c|}{ Wiek } \\
\hline \multicolumn{2}{|c|}{ 20-35 lat } & \multicolumn{2}{|c|}{ 36-50 lat } & powyżej 50 lat \\
\hline \multicolumn{2}{|c|}{$24,07 \%$} & \multicolumn{2}{|c|}{$46,30 \%$} & $29,63 \%$ \\
\hline \multicolumn{5}{|c|}{ Płeć } \\
\hline \multicolumn{4}{|c|}{ kobieta } & mężczyzna \\
\hline \multicolumn{4}{|c|}{$22,22 \%$} & $77,78 \%$ \\
\hline \multicolumn{5}{|c|}{ Wykształcenie } \\
\hline \multicolumn{2}{|c|}{ podstawowe } & \multicolumn{2}{|c|}{ średnie } & wyższe \\
\hline \multicolumn{2}{|l|}{$0 \%$} & \multicolumn{2}{|c|}{$5,56 \%$} & $94,44 \%$ \\
\hline \multicolumn{5}{|c|}{ Doświadczenie biznesowe } \\
\hline \multicolumn{2}{|c|}{ 1-10 lat pracy } & \multicolumn{2}{|c|}{ 11-20 lat pracy } & owyżej 20 lat pracy \\
\hline \multicolumn{2}{|c|}{$14,82 \%$} & \multicolumn{2}{|c|}{$53,70 \%$} & $31,48 \%$ \\
\hline \multicolumn{5}{|c|}{ Charakter prowadzonej działalności } \\
\hline \multicolumn{2}{|c|}{ produkcja przemysłowa } & \multicolumn{2}{|c|}{ usługi } & handel \\
\hline \multicolumn{2}{|l|}{$9,26 \%$} & \multicolumn{2}{|c|}{$66,67 \%$} & $9,26 \%$ \\
\hline \multicolumn{3}{|c|}{ budownictwo } & & $\mathrm{ane}^{*}$ \\
\hline \multicolumn{2}{|c|}{$3,70 \%$} & & & $1,11 \%$ \\
\hline & & & ębior & \\
\hline $\begin{array}{c}\text { poniżej } 10 \\
\text { pracowników }\end{array}$ & & & $\begin{array}{r}50 \\
\text { praco }\end{array}$ & $\begin{array}{c}\text { powyżej } \\
250 \text { pracowników }\end{array}$ \\
\hline $47,17 \%$ & & & & $13,21 \%$ \\
\hline
\end{tabular}

*Wśród innej działalności wskazano: ubezpieczenia, branżę artystyczno-wydawnicza, administrację, naukę i badania, Venture Capital.

Źródło: opracowanie własne na podstawie danych przekazanych przez firmę F5 Konsulting.

${ }^{13}$ Należy jednoznacznie podkreślić, że badanie nie jest reprezentatywne dla całego środowiska gospodarczego aglomeracji poznańskiej, dobór próby badawczej był bowiem celowy. Wyników tych nie można zatem odnosić do całej populacji przedsiębiorców prowadzących działalność na terenie aglomeracji. Badanie ma niewątpliwie charakter pilotażowy, a jego wyniki pokazuja, że należałoby kontynuować je w rozszerzonej formule. 
Blisko połowa ankietowanych przedsiębiorców to osoby z grupy wiekowej 36-50 lat, 24\% respondentów to osoby w wieku 20-35 lat, pozostali zaś maja powyżej 50 lat. W badanej grupie większość stanowili mężczyźni, było to bowiem aż $77 \%$. Dominowały także osoby legitymujące się wyższym wykształceniem (blisko 95\%). Jeśli chodzi o doświadczenie biznesowe, to najwięcej było osób prowadzących swoją działalność od 11-20 lat (prawie 54\%), blisko co trzeci badany legitymował się ponad 20-letnim doświadczeniem, natomiast pozostali mieścili się w przedziale 1-10 lat. Wśród osób biorących udział w badaniu dominowali przedsiębiorcy prowadzący działalność o charakterze usługowym, było to bowiem blisko 7 na 10 pytanych osób. Wreszcie w badaniu większość stanowiły osoby zatrudniające poniżej 10 pracowników, a następnie osoby zatrudniajace od 10 do 50 osób.

Pytanie pierwsze brzmiało: „Czy Pana/Pani firma należy do jakiejkolwiek organizacji zrzeszajacej przedsiębiorców?”. Dokładnie połowa respondentów potwierdziła swoją przynależność do organizacji zrzeszających przedsiębiorców i analogicznie 50\% pytanych osób stwierdziło, że nie należy do żadnej organizacji zrzeszającej przedsiębiorców.

W punkcie drugim ankiety poproszono osoby deklarujace przynależność do jakiejś organizacji o wskazanie jej charakteru. Najbardziej popularnym jej typem okazały się izby przemysłowo-handlowe, izby gospodarcze oraz stowarzyszenia przedsiębiorców. Szczegółowe zestawienie przynależności do danej organizacji zawiera tabela 2 .

\section{Tabela 2}

Przynależność do danej organizacji*

\begin{tabular}{|c|c|c|}
\hline $\begin{array}{c}\text { izba przemysłowo- } \\
\text {-handlowa }\end{array}$ & izba gospodarcza & izba budownictwa \\
\hline $48,15 \%$ & $24,07 \%$ & $7,40 \%$ \\
\hline cech, izba rzemieślnicza & zrzeszenie handlu i usług & zrzeszenie transportu \\
\hline $0 \%$ & $0 \%$ & $0 \%$ \\
\hline izba turystyczna & $\begin{array}{c}\text { stowarzyszenie przedsię- } \\
\text { biorców }\end{array}$ & inne* \\
\hline $0 \%$ & $24,07 \%$ & $24,07 \%$ \\
\hline
\end{tabular}

* Należy zaznaczyć, że zsumowanie wyników nie daje 100\%, respondenci bowiem mieli możliwość dokonania wielokrotnego wyboru.

** Wśród innych respondenci wskazali, takie jak: Konfederacja Pracodawców, Wielkopolski Klub Kapitału, stowarzyszenie branżowe, Konwent, p-team - spotkania ludzi przedsiębiorczych, strefa ekonomiczna, fundacja.

Źródło: opracowanie własne na podstawie danych przekazanych przez firmę F5 Konsulting.

W punkcie trzecim poproszono osoby nienależace do żadnej organizacji zrzeszającej przedsiębiorców o wyjaśnienie, dlaczego do tej pory nie przystapiły do tego typu instytucji. Przedsiębiorcy niezrzeszeni jako główne czynniki 
decydujące o braku przynależności do organizacji wskazali: brak czasu, niechęć do zapłaty składek członkowskich, brak wiary w efektywność tego typu działań oraz brak korzyści wynikających z takiej przynależności. Szczegółowe zestawienie odpowiedzi respondentów pokazuje wykres 1 .

\section{Wykres 1}

Powody braku przynależności do organizacji zrzeszających przedsiębiorców

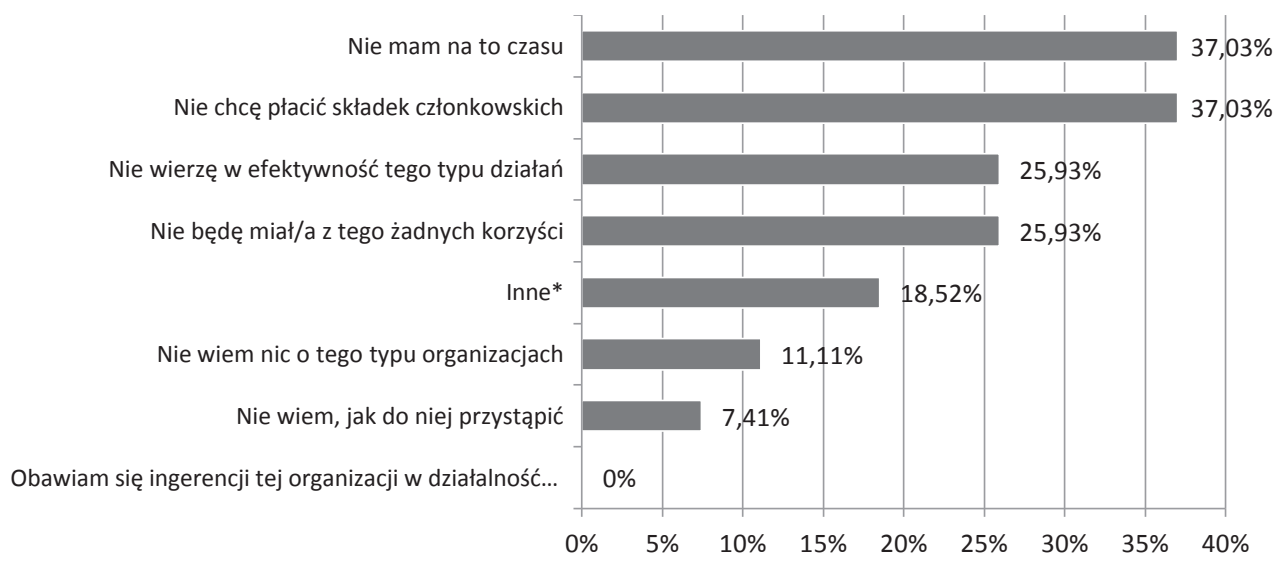

* Wśród innych ankietowani zaznaczali, że: istniejące organizacje sa zbyt upolitycznione, posiadaja skostniałe struktury i nie zajmują się wymianą wiedzy i budowaniem networkingu, nie biorą pod uwagę możliwości członkostwa oraz trudno powiedzieć.

Źródło: opracowanie własne na podstawie danych przekazanych przez firmę F5 Konsulting.

Pytanie czwarte brzmiało: „Jeżeli Pana/Pani firma nie należy do organizacji zrzeszającej przedsiębiorców, to czy chciałby/łaby Pan/Pani do niej przystąpić?". Większość pytanych osób (ponad 48\%) odpowiedziała negatywnie na tak postawione pytanie. Co czwarta pytana osoba stwierdziła, że jest to trudne do określenia. Również co czwarty pytany przedsiębiorca wyraził wolę przystąpienia do organizacji zrzeszającej przedsiębiorców. Widać więc wyraźnie, że zaledwie $26 \%$ niezrzeszonych przedsiębiorców wyraża chęć przystapienia do takiej organizacji. Natomiast aż $75 \%$ badanych osób nie zamierza w najbliższym czasie dołączyć do jakiejkolwiek organizacji, której zadaniem jest reprezentacja interesów przedsiębiorców. Szczegółowe zestawienie pokazuje wykres 2.

W punkcie piątym zapytano ankietowanych wprost: „Czy uważa Pan/Pani, że samorząd gospodarczy jest potrzebny?”. Zdecydowana większość pytanych osób uznała, że samorząd gospodarczy jest potrzebny (74\%). Co piąty pytany przedsiębiorca nie był w stanie jasno określić swojego stanowiska. Niespełna $6 \%$ osób pytanych uznała, że samorząd gospodarczy jest niepotrzebny. Zestawienie odpowiedzi respondentów prezentuje wykres 3. 


\section{Wykres 2}

Odpowiedzi przedsiębiorców na pytanie 4

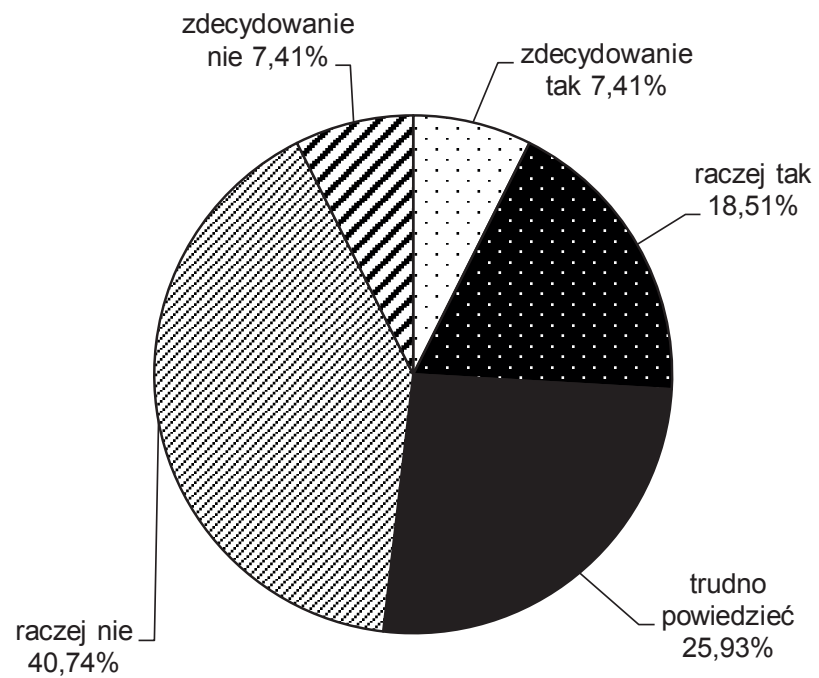

Źródło: opracowanie własne na podstawie danych przekazanych przez firmę F5 Konsulting.

\section{Wykres 3}

Odpowiedzi przedsiębiorców na pytanie 5

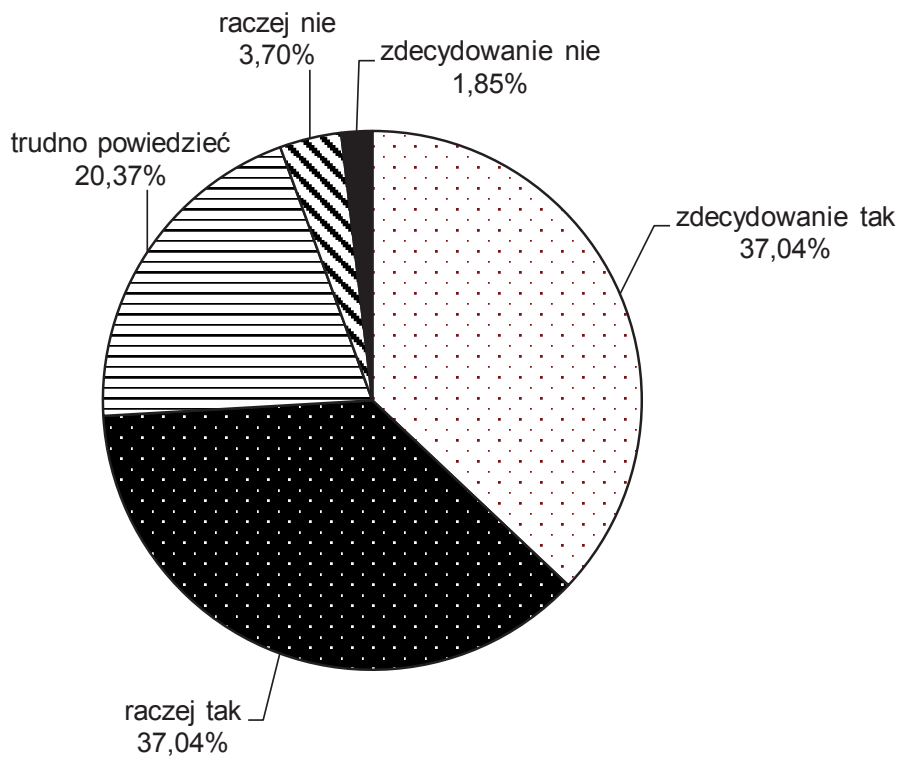

Źródło: opracowanie własne na podstawie danych przekazanych przez firmę F5 Konsulting. 
Pytanie szóste brzmiało: „Czy znane są Panu/Pani zasady działania samorządu gospodarczego?”. Większość pytanych osób uznała, że zna zasady działania samorządu gospodarczego, jednak blisko trzech spośród pięciu respondentów uznało, że tych zasad nie zna. Szczegółowe zestawienie pokazuje wykres 4 .

Wykres 4

Odpowiedzi przedsiębiorców na pytanie 6

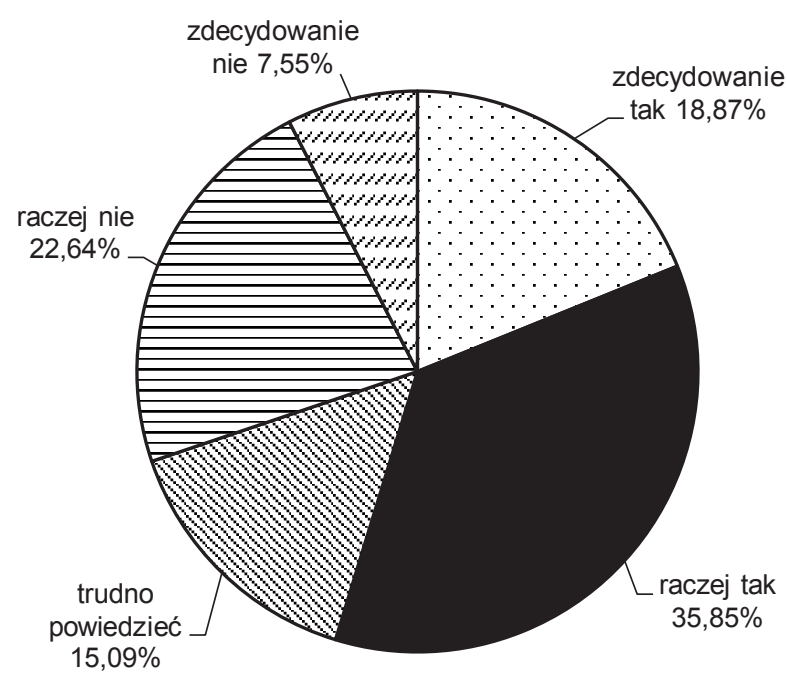

Źródło: opracowanie własne na podstawie danych przekazanych przez firmę F5 Konsulting.

Jeśli jednak uznać, że odpowiedź „trudno powiedzieć” również oznacza brak wiedzy na temat funkcjonowania samorządu gospodarczego, to okazuje się, że blisko połowa osób nie dysponuje ugruntowaną wiedzą na temat zasad funkcjonowania samorządu gospodarczego. Warto także porównać odpowiedzi osób, uwzględniając fakt bycia członkiem jakiejkolwiek organizacji zrzeszającej przedsiębiorców. Okazuje się bowiem, że przynależność do takiej instytucji nie warunkuje wzrostu znajomości zasad funkcjonowania samorzadu gospodarczego, co pokazuje wykres 5 .

W punkcie siódmym zapytano ankietowanych: „Czy uważa Pan/Pani, że przynależność do samorządu gospodarczego powinna być obowiązkowa?”. Zdecydowana większość przedsiębiorców uznała, że przynależność do samorządu gospodarczego powinna mieć charakter dobrowolny. Zaledwie co piąta osoba uznała, że członkostwo w samorządzie powinno mieć charakter obligatoryjny. Nie ulega więc wątpliwości, że perspektywa obowiązkowej przynależności do samorządu gospodarczego jest czynnikiem odstraszającym przedsiębiorców od członkostwa w organizacjach reprezentujących środowiska gospodarcze. 


\section{Wykres 5}

Odpowiedzi przedsiębiorców na pytanie 6 z uwzględnieniem przynależności do jakiejkolwiek organizacji zrzeszającej przedsiębiorców

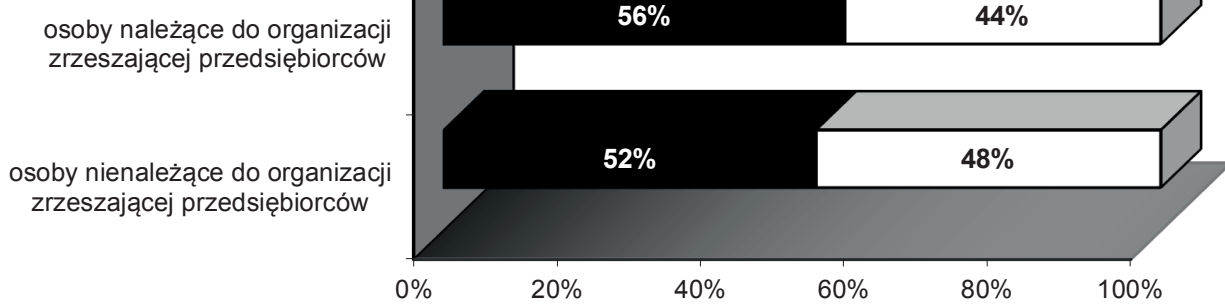

Źródło: opracowanie własne na podstawie danych przekazanych przez firmę F5 Konsulting.

Pamiętając o modelowych założeniach dotyczących samorządu gospodarczego, należy zauważyć, że badani przedsiębiorcy, wbrew deklaracjom zaprezentowanym w ankiecie, nie dysponują zadowalająca wiedzą na temat istoty i zakresu zadań samorządu gospodarczego. Szczegółowe zestawienie odpowiedzi respondentów pokazuje wykres 6 .

\section{Wykres 6}

Odpowiedzi przedsiębiorców na pytanie 7

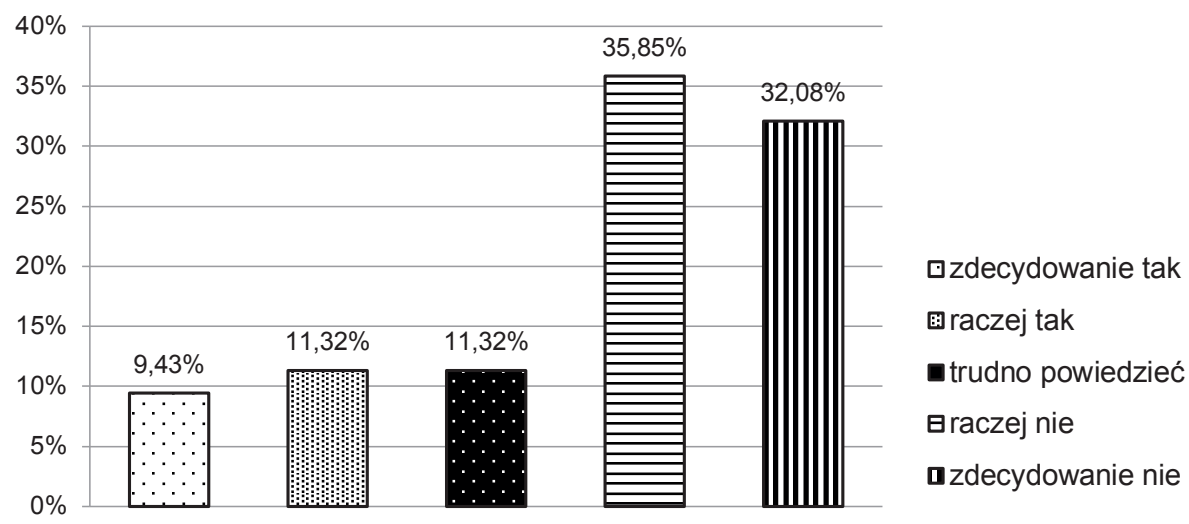

Źródło: opracowanie własne na podstawie danych przekazanych przez firmę F5 Konsulting.

Pytanie ósme brzmiało: „Czy uważa Pan/Pani, że samorząd gospodarczy może pozytywnie wpłynać na rozwój rynku i przedsiębiorczości?”. Zdecydowana większość osób, blisko 7 na 10 pytanych bowiem uznało, że samorząd gospo- 
darczy może pozytywnie wpłynąć na rozwój rynku i przedsiębiorczości. Mimo więc obawy przed obowiązkową przynależnością do samorządu gospodarczego respondenci w większości uznali, że jego funkcjonowanie nie stoi w sprzeczności z ideą wolnego rynku czy też przedsiębiorczości. Zaledwie nieco ponad 7\% pytanych osób było przeciwnego zdania. Szczegółowe zestawienie odpowiedzi ankietowanych prezentuje wykres 7 .

Wykres 7

Odpowiedzi przedsiębiorców na pytanie 8

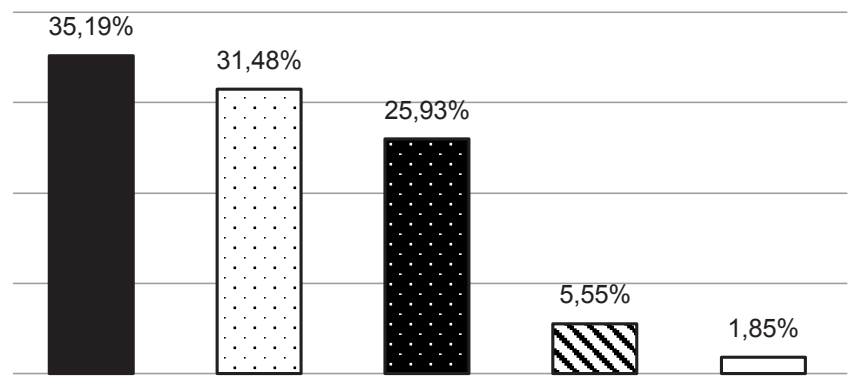

-zdecydowanie tak

Đraczej tak

- trudno powiedzieć

बraczej nie

azdecydowanie nie

Źródło: opracowanie własne na podstawie danych przekazanych przez firmę F5 Konsulting.

W punkcie dziewiątym zapytano ankietowanych: „Czy uważa Pan/Pani, że samorząd gospodarczy przyczyni się do integracji środowiska przedsiębiorców?". W przypadku tego pytania odsetek osób, które udzieliły pozytywnej odpowiedzi, był zdecydowanie najwyższy. Niespełna 10\% pytanych osób było odmiennego zdania, natomiast jedna piąta osób była niezdecydowana. Szczegółowe zestawienie odpowiedzi ankietowanych przedsiębiorców prezentuje wykres 8 .

Wykres 8

Odpowiedzi przedsiębiorców na pytanie 9

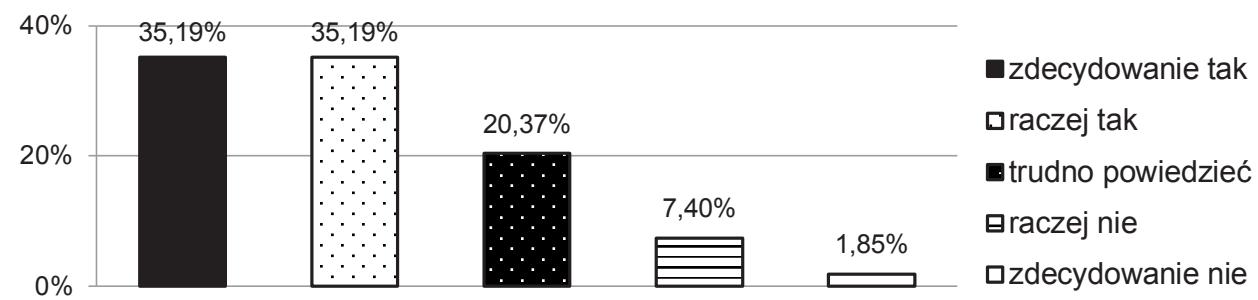

Źródło: opracowanie własne na podstawie danych przekazanych przez firmę F5 Konsulting. 
W kolejnym punkcie ankiety zapytano respondentów: „Czy uważa Pan/ Pani, że samorząd gospodarczy może pozytywnie wpłynąć na upowszechnienie zasad etyki w działalności gospodarczej?”. Respondenci zdecydowanie uznali, że istnienie i sprawne funkcjonowanie samorządu gospodarczego może pozytywnie wpłynać na upowszechnienie zasad etyki w działalności gospodarczej. Co istotne, żaden z ankietowanych nie wybrał odpowiedzi „zdecydowanie nie”, co szczegółowo ilustruje wykres 9.

Wykres 9

Odpowiedzi przedsiębiorców na pytanie 10

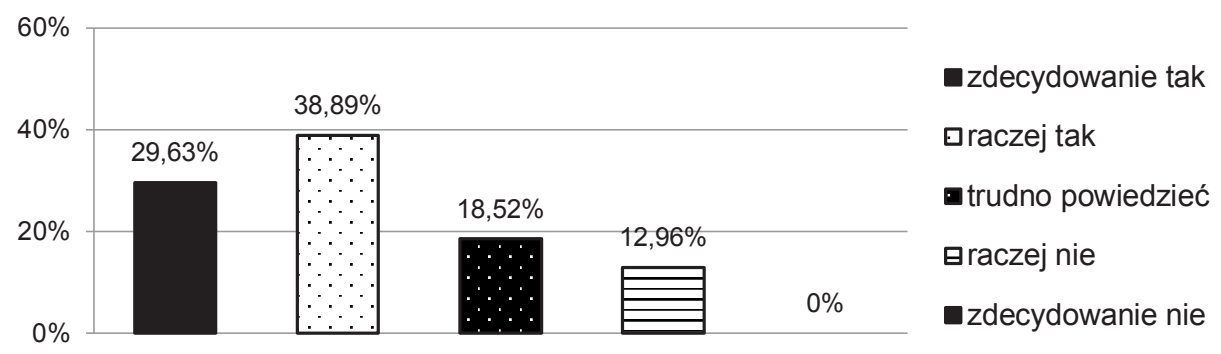

Źródło: opracowanie własne na podstawie danych przekazanych przez firmę F5 Konsulting.

W punkcie jedenastym zapytano przedsiębiorców: „Jak Pan/Pani ocenia swój dotychczasowy wpływ na decyzje podejmowane przez władze rządowe i samorządowe w dziedzinie prowadzenia działalności gospodarczej?”. Większość respondentów zgodnie uznała (55\%), że nie miała ona realnego wpływu na decyzje podejmowane przez władze rządowe i samorządowe w sprawach rodzajowo związanych z prowadzeniem działalności gospodarczej. Szczegółowe zestawienie odpowiedzi ankietowanych prezentuje wykres 10 .

Wykres 10

Odpowiedzi przedsiębiorców na pytanie 11

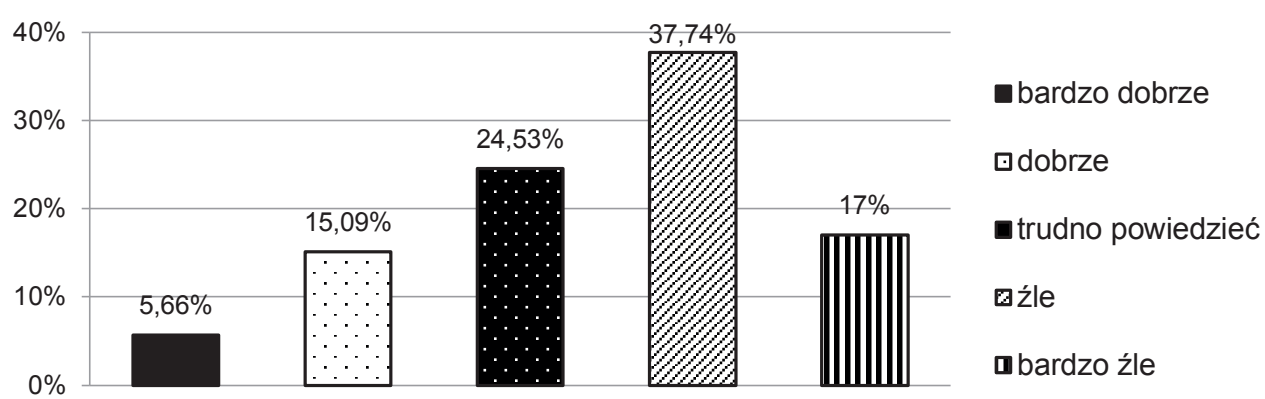

Źródło: opracowanie własne na podstawie danych przekazanych przez firmę F5 Konsulting. 
W punkcie dwunastym ankiety zapytano respondentów, czy są jeszcze sprawy, o które nie pytano, a są one istotne z punktu widzenia prowadzonego badania. Z takiej możliwości skorzystało 5 osób, z tym że jedna uznała, iż takich spraw nie ma. Inny przedsiębiorca stwierdził, że model i zasady funkcjonowania samorządu gospodarczego są istotnym elementem majacym wpływ na decyzję przedsiębiorców o przynależności do niego. Zdaniem tej osoby, aby zachęcić przedsiębiorców do przystapienia do samorządu gospodarczego, należy jasno określić zasady jego funkcjonowania. Inny $\mathrm{z}$ ankietowanych zwrócił uwagę na dwie sprawy, a mianowicie na kwestię lobbingu - pytając o jego granice oraz etyczność, a także na kwestię relacji między wielkimi i małymi przedsiębiorcami - pytając, jak utrzymać równowagę między nimi, jakie mogą występować w związku z tym szanse oraz zagrożenia. Kolejny z ankietowanych zaznaczył, że należałoby zwrócić uwagę na wpływ samorządu gospodarczego i stowarzyszeń przedsiębiorców na wspólne działania w kierunku adaptacji warunków konsolidacji z przepisami Unii Europejskiej.

Wreszcie pojawił się głos krytyczny, w którym zdecydowanie skomentowano dotychczasowe relacje między władzami samorządowymi, organizacjami zrzeszającymi przedsiębiorców oraz samymi przedsiębiorcami. Respondent stwierdził, że: „Pomimo szczególnej roli MŚP w procesie generowania dochodu w Polsce, jest zbyt mało programów do nich kierowanych. Fundusze unijne sa skomplikowane i biurokratyczne, stąd wiele firm nie decyduje się na udział w szkoleniach/warsztatach bądź pisze projekty pod założenia projektu, a nie własne potrzeby. Poza tym koszty administracyjne »zjadają" nawet 50\% przyznanych środków, i to zarówno tych wpisanych w projekt, jak i tych, które są do poniesienia, a rozliczyć ich nie można. Administracja samorządowa zachowuje się bardziej jak audytor i kontroler niż podmiot wspierający i przejmujący część obowiązków na siebie. Zrzeszania przedsiębiorców nie mają znaczącego wpływu na działania samorządu, bo po drugiej stronie mają urzędników, a nie elastycznych przedsiębiorców oraz zbyt sztywne prawo. Stąd propozycja, by każdy potencjalny pracownik samorządu/urzędu miał obowiązek przepracować co najmniej 2 lata w tzw. biznesie. Może to zaowocować lepszym zrozumieniem problematyki gospodarczej, większymi kompetencjami pracowników samorządowych, a tym samym większą elastycznością działania i lepszym współdziałaniem z przedsiębiorcami”. Ten krytyczny głos wyraźnie pokazuje, że wielostronna relacja samorząd - organizacja przedsiębiorców - przedsiębiorca jest bardzo złożona.

W ramach prowadzonego badania warto też sprawdzić, czy odpowiedzi respondentów różnią się między soba, jeśli uwzględni się jedno z kryteriów metryczkowych, a więc: wiek, płeć, wykształcenie, doświadczenie biznesowe, charakter prowadzonej działalności lub wielkość przedsiębiorstwa. Otóż okazuje się, że największe zróżnicowanie odpowiedzi wystapiło przy uwzględnieniu wieku respondentów, co szczegółowo obrazuje tabela 3. 
Tabela 3

Odpowiedzi respondentów na wybrane pytania (z uwzględnieniem wieku respondentów)*

\begin{tabular}{|c|c|c|c|c|c|}
\hline \multicolumn{6}{|c|}{ Czy samorząd gospodarczy jest potrzebny? } \\
\hline \multicolumn{2}{|c|}{ 20-35 lat } & \multicolumn{2}{|c|}{ 36-50 lat } & \multicolumn{2}{|c|}{ powyżej 50 lat } \\
\hline pozytywne & negatywne & pozytywne & negatywne & pozytywne & negatywne \\
\hline $54 \%$ & $0 \%$ & $80 \%$ & $20 \%$ & $81 \%$ & $6 \%$ \\
\hline \multicolumn{6}{|c|}{ Czy znane są Panu/Pani zasady działania samorządu gospodarczego? } \\
\hline \multicolumn{2}{|c|}{ 20-35 lat } & \multicolumn{2}{|c|}{ 36-50 lat } & \multicolumn{2}{|c|}{ powyżej 50 lat } \\
\hline pozytywne & negatywne & pozytywne & negatywne & pozytywne & negatywne \\
\hline $38 \%$ & $46 \%$ & $44 \%$ & $32 \%$ & $81 \%$ & $12 \%$ \\
\hline
\end{tabular}

Czy uważa Pan/Pani, że przynależność do samorządu gospodarczego powinna być obowiązkowa?

\begin{tabular}{|c|c|c|c|c|c|}
\hline \multicolumn{2}{|c|}{ 20-35 lat } & \multicolumn{2}{c|}{ 36-50 lat } & \multicolumn{2}{c|}{ powyżej 50 lat } \\
\hline pozytywne & negatywne & pozytywne & negatywne & pozytywne & negatywne \\
\hline $15 \%$ & $69 \%$ & $16 \%$ & $76 \%$ & $31 \%$ & $50 \%$ \\
\hline
\end{tabular}

Czy uważa Pan/Pani, że samorząd gospodarczy może pozytywnie wpłynąć na rozwój rynku i przedsiębiorczości?

\begin{tabular}{|c|c|c|c|c|c|}
\hline \multicolumn{2}{|c|}{ 20-35 lat } & \multicolumn{2}{c|}{$\mathbf{3 6 - 5 0}$ lat } & \multicolumn{2}{c|}{ powyżej 50 lat } \\
\hline pozytywne & negatywne & pozytywne & negatywne & pozytywne & negatywne \\
\hline $38 \%$ & $0 \%$ & $64 \%$ & $12 \%$ & $94 \%$ & $6 \%$ \\
\hline
\end{tabular}

Czy uważa Pan/Pani, że samorząd gospodarczy przyczyni się do integracji środowiska przedsiębiorców?

\begin{tabular}{|c|c|c|c|c|c|}
\hline \multicolumn{2}{|c|}{$\mathbf{2 0 - 3 5}$ lat } & \multicolumn{2}{c|}{$\mathbf{3 6 - 5 0}$ lat } & \multicolumn{2}{c|}{ powyżej 50 lat } \\
\hline pozytywne & negatywne & pozytywne & negatywne & pozytywne & negatywne \\
\hline $54 \%$ & $0 \%$ & $68 \%$ & $12 \%$ & $88 \%$ & $6 \%$ \\
\hline
\end{tabular}

Czy uważa Pan/Pani, że samorząd gospodarczy może pozytywnie wpłynąć na upowszechnienie zasad etyki w działalności gospodarczej?

\begin{tabular}{|c|c|c|c|c|c|}
\hline \multicolumn{2}{|c|}{ 20-35 lat } & \multicolumn{2}{c|}{ 36-50 lat } & \multicolumn{2}{c|}{ powyżej 50 lat } \\
\hline pozytywne & negatywne & pozytywne & negatywne & pozytywne & negatywne \\
\hline $46 \%$ & $23 \%$ & $60 \%$ & $0 \%$ & $81 \%$ & $0 \%$ \\
\hline
\end{tabular}

Jak Pan/Pani ocenia swój dotychczasowy wpływ na decyzje podejmowane przez władze rządowe i samorządowe w dziedzinie prowadzenia działalności gospodarczej?

\begin{tabular}{|c|c|c|c|c|c|}
\hline \multicolumn{2}{|c|}{ 20-35 lat } & \multicolumn{2}{c|}{$\mathbf{3 6 - 5 0}$ lat } & \multicolumn{2}{c|}{ powyżej 50 lat } \\
\hline pozytywne & negatywne & pozytywne & negatywne & pozytywne & negatywne \\
\hline $31 \%$ & $38 \%$ & $72 \%$ & $16 \%$ & $19 \%$ & $63 \%$ \\
\hline
\end{tabular}

*W niniejszej analizie pominięto odpowiedź „trudno powiedzieć”.

Źródło: opracowanie własne na podstawie danych przekazanych przez firmę F5 Konsulting. 
Z powyższego zestawienia wynika, że młodzi przedsiębiorcy z rezerwą odnoszą się do kwestii powołania samorządu gospodarczego, natomiast osoby starsze w zdecydowanej większości wyrażają poparcie dla takiego pomysłu. Podobnie sprawa wygląda w przypadku pytania o znajomość zasad funkcjonowania samorządu gospodarczego. Otóż wraz z wiekiem respondentów rośnie również liczba osób deklarujących znajomość reguł działania samorządu gospodarczego, stan wiedzy z tego zakresu wśród najmłodszych respondentów jest bowiem dwukrotnie niższy aniżeli wśród osób starszych. W przypadku pytania o obowiązkową przynależność do samorządu gospodarczego widać wyraźnie, że ten pomysł zyskuje poparcie, ale tylko w grupie najstarszych przedsiębiorców. Mimo tego w każdym przedziale wiekowym zdecydowanie przeważają osoby, które uznają obowiązkową przynależność do struktur samorządowych za niepożądana. Najstarsi respondenci niemal trzykrotnie częściej aniżeli najmłodsi i prawie dwukrotnie częściej niż osoby ze średniego przedziału wiekowego uznali, że samorząd gospodarczy może pozytywnie wpłynąć na rozwój rynku i przedsiębiorczości. Podobna tendencja wystąiła w przypadku pytania dotyczącego korzyści, jakie może przynieść samorząd gospodarczy w kwestii integracji środowiska przedsiębiorców. Tutaj ponownie, wraz ze wzrostem wieku przedsiębiorcy, zwiększało się poparcie dla takiego poglądu. Wyniki badania wskazują również, że podobna korelacja między wiekiem a odpowiedziami ankietowanych miała miejsce w przypadku pytania o to, czy samorząd gospodarczy może pozytywnie wpłynąc na upowszechnienie zasad etyki w działalności gospodarczej. Starsi przedsiębiorcy upatrują w samorządzie szansy na rozpowszechnienie etycznych postaw w działalności biznesowej niemal dwukrotnie częściej aniżeli ich młodsi koledzy. Wreszcie gdy poproszono przedsiębiorców o ocenę swojego dotychczasowego wpływu na decyzje podejmowane przez władze rządowe i samorządowe w dziedzinie prowadzenia działalności gospodarczej, okazało się, że najgorzej swoje osiagnięcia w tym zakresie ceniły osoby najstarsze. Z kolei najlepiej kwestię wpływu na bieg wydarzeń w sprawach gospodarczych ocenili przedsiębiorcy z przedziału wiekowego 36-50 lat.

Aby podsumować przeprowadzone badanie ankietowe dotyczace opinii wielkopolskich przedsiębiorców na temat organizacji zrzeszających przedsiębiorców oraz samorządu gospodarczego, warto spojrzeć na diagram 1, w którym porównano odpowiedzi respondentów na wybrane pytania.

Spośród wszystkich badanych 50\% osób potwierdziło swoją przynależność do organizacji zrzeszających przedsiębiorców, natomiast zaledwie $26 \%$ przedsiębiorców niezrzeszonych wyraziło wolę przystapienia do organizacji. Z ogółu badanych osób 54\% zadeklarowało znajomość zasad działania samorządu gospodarczego. Co bardzo istotne i niepokojace zarazem, w grupie przedsiębiorców należących do organizacji zrzeszających przedsiębiorców aż 44\% nie zna zasad funkcjonowania samorządu gospodarczego. Zdecydowana większość ankietowanych, gdyż aż 68\%, odpowiedziała, że przynależność do samorządu gospodarczego powinna mieć charakter dobrowolny, co jest sprzeczne z publicznoprawnym charakterem samorządu, na co zwrócono uwagę w pierwszej części tego opracowania. Wreszcie 55\% badanych przedsiębiorców oceniło, że nie miało dotychczas wpływu na decyzje podejmowane w dziedzinie prowadzenia działalności gospodarczej przez władze rządowe i samorządowe. 


\section{Diagram 1}

Porównanie odpowiedzi respondentów na wybrane pytania

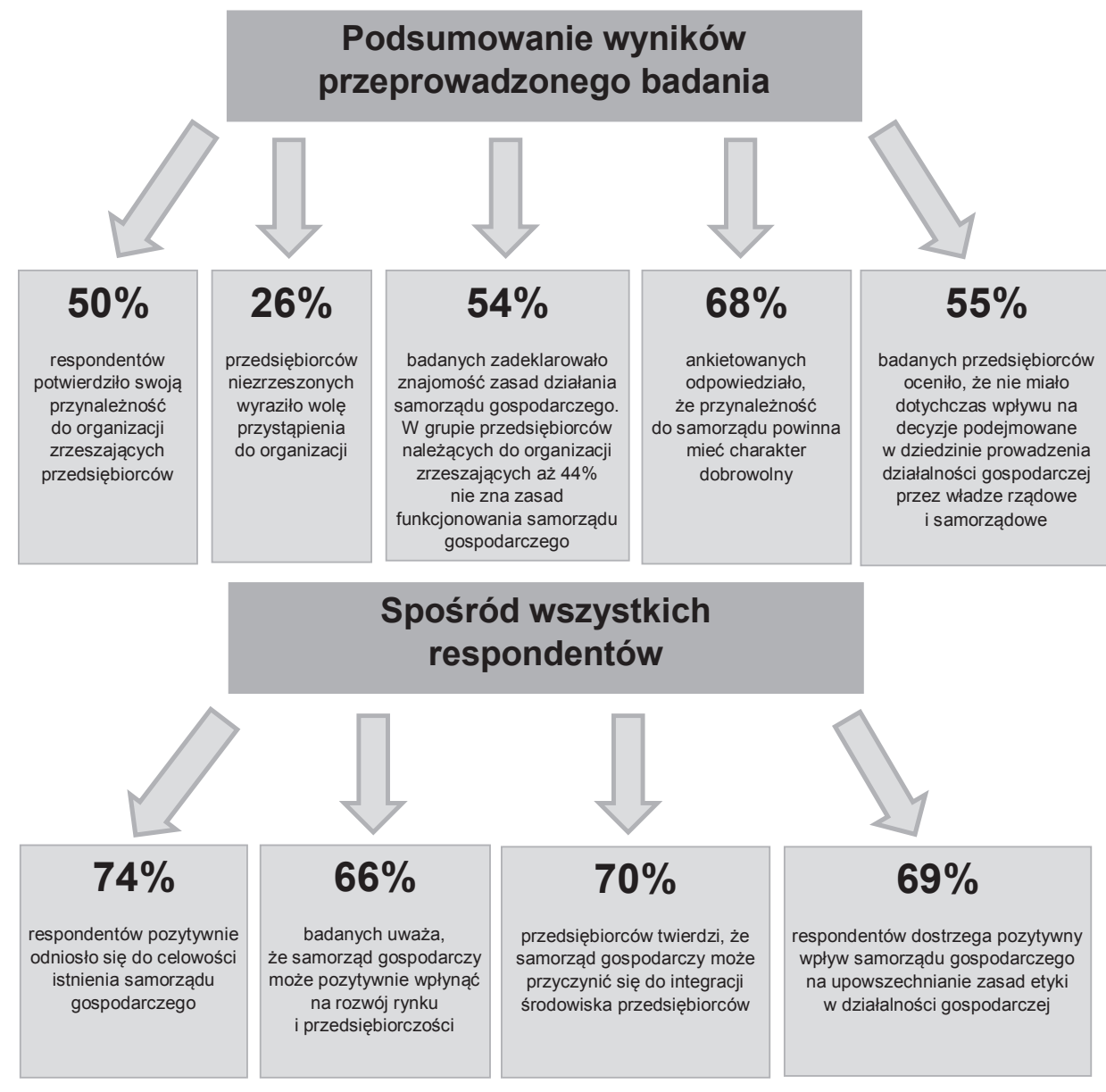

Źródło: opracowanie firma F5 Konsulting.

Z drugiej strony przedsiębiorcy dostrzegają liczne korzyści, jakie mogłoby przynieść wprowadzenie powszechnego samorządu gospodarczego. Przede wszystkim 74\% respondentów pozytywnie odniosło się do celowości istnienia samorządu gospodarczego. Ponadto 66\% badanych uważa, że samorząd gospodarczy może pozytywnie wpłynacc na rozwój rynku i przedsiębiorczości. Jeszcze więcej osób, gdyż aż 70\% badanych, stwierdziło, że samorząd gospodarczy może przyczynić się do integracji środowiska przedsiębiorców. Wreszcie, co bardzo istotne, 69\% respondentów dostrzega pozytywny wpływ samorządu gospodarczego na upowszechnianie zasad etyki w działalności gospodarczej.

Z przedstawionego powyżej opisu i diagramu 1 wynika jednoznacznie, że odpowiedzi przedsiębiorców w kwestiach dotyczących samorządu gospodarcze- 
go są bardzo niespójne. Z jednej strony przedsiębiorcy wydają się entuzjastami pomysłu wprowadzenia samorządu gospodarczego w polskim modelu ustrojowym. Z drugiej jednak - widać wyraźnie, że nie posiadają oni dostatecznej wiedzy na temat jego istoty oraz mechanizmów funkcjonowania, neguja oni bowiem jedną z jego podstawowych cech, a więc obowiązkową przynależność.

Nie ulega wątpliwości, że przedsiębiorcy nie są na tyle zorganizowani oraz zdeterminowani, aby prowadzić efektywne działania na rzecz wprowadzenia samorządu gospodarczego w Polsce. Niewielki odsetek osób, które podjęły trud wypełnienia elektronicznej ankiety (7,71\%), pokazuje, że środowisko przedsiębiorców nie jest szczególnie zainteresowane działalnością w tej materii. Wśród osób, które poświęciły swój czas i rzetelnie odpowiedziały na postawione w badaniu pytania, widać wyraźnie, że nie do końca zdają one sobie sprawę, czym $\mathrm{w}$ istocie miałby być samorząd gospodarczy, jakie to niosłoby realne koszty i korzyści dla przeciętnego przedsiębiorcy oraz co zmieniłoby się w codziennym prowadzeniu działalności gospodarczej.

Widać również wyraźnie, że występuja istotne różnice w odpowiedziach respondentów, biorąc pod uwagę ich wiek. Młodzi przedsiębiorcy bardziej krytycznie odnoszą się do kwestii powołania samorządu gospodarczego, posiadaja mniejszą wiedzę na temat zasad jego funkcjonowania, nie są zwolennikami obowiązkowej przynależności do samorządu, w znacznie mniejszym stopniu aniżeli osoby starsze uznaja, że samorząd gospodarczy może pozytywnie wpłynąć na rozwój rynku i przedsiębiorczości, integrować środowisko przedsiębiorców oraz upowszechnieniać zasady etyki w działalności gospodarczej. Sceptyczna postawa młodych przedsiębiorców jest szczególnie niepokojąca w kontekście perspektyw ustanowienia i rozwoju w Polsce realnego, opartego na publicznoprawnych formach działania samorządu gospodarczego.

Omówione badanie skłania do sformułowania co najmniej dwóch postulatów na przyszłość. Po pierwsze, istotne jest rozwinięcie działalności edukacyjnej z zakresu samorządu gospodarczego. Należy wskazać na zalety tej formy organizacji środowiska społecznego przedsiębiorców w kontekście przewidywanego kształtowania się systemu wieloszczeblowego zarządzania. Po drugie, niezbędne jest zintensyfikowanie badań dotyczących tej kwestii. Przedsiębiorczość lokalna lub regionalna stanowi fundament rozwoju społeczno-gospodarczego. Stąd też współpraca na linii władze samorządowe - samorząd gospodarczy stanowić może istotny element $\mathrm{w}$ procesie podejmowania decyzji publicznych.

\section{PODSUMOWANIE}

Nie ulega wątpliwości, że spośród wszystkich organizacji zajmujących się rzecznictwem interesów przedsiębiorców najważniejszą rolę powinny odgrywać obligatoryjne, trwale osadzone w strukturze ustrojowej kraju izby przemysłowo-handlowe. To właśnie izbom, a nie stowarzyszeniom gospodarczym, należy przyznać status jednostek powszechnego samorządu gospodarczego, za którym stoją ustawowo określone kompetencje z zakresu władztwa admini- 
stracyjnego. Powszechność oznacza w tym przypadku: obligatoryjność członkostwa, oparty na systemie demokratycznych wyborów sposób wyłaniania władz samorządowych oraz ich partycypowanie w podziale kompetencji administracyjnych. Taka struktura organizacyjna umożliwi udoskonalenie relacji pomiędzy środowiskiem gospodarczym a samorządem terytorialnym. Dążenie do modyfikacji funkcjonującego obecnie systemu jest widoczne po stronie obu partnerów. Ta okoliczność skłania do opowiedzenia się za samorządem gospodarczym jako integralnym elementem systemu politycznego, równoprawnym w granicach ustawy partnerem administracji rządowej i samorządu terytorialnego. Osiagnięcie tego celu, w pełni zgodnego z istotą samorządu, wymagać jednak będzie daleko idącego kompromisu pomiędzy wszystkimi uczestnikami procesu kształtowania stosunków społeczno-gospodarczych w Polsce.

Konsekwencją wskazanego powyżej postulatu powinno stać się przyznanie samorządowi gospodarczemu realnego wpływu na proces decyzyjny w zakresie funkcjonowania gospodarki. Tylko w takiej sytuacji środowisko gospodarcze będzie traktowane w sposób podmiotowy, co powinno sprzyjać szerszym reformom samorządowym zmierzajacym w kierunku utworzenia systemu wieloszczeblowego zarządzania. W rezultacie udział przedsiębiorców w podejmowaniu decyzji publicznych w sferze gospodarczej na poziomie lokalnym będzie znacznie efektywniejszy.

dr Pawet Antkowiak

Uniwersytet im. Adama Mickiewicza w Poznaniu

pawela@amu.edu.pl

dr hab. Robert Kmieciak

Profesor Uniwersytetu im. Adama Mickiewicza w Poznaniu

robert.kmieciak@amu.edu.pl

\section{ENTREPRENEUR PARTICIPATION IN THE PUBLIC ECONOMIC DECISION-MAKING PROCESS AT A LOCAL LEVEL}

\section{Sum mary}

Nowadays, outdated local policy-making is exhausted. It seems that we should increasingly incorporate other - external entities into the management structure in order to streamline and rationalize the process of public decision-making, which directly affects the economic development of the region. The answer to this need is the concept of public management. The group which in the opinion of the authors should have an impact on public decision-making in the economic sphere, are undoubtedly the entrepreneurs. Unfortunately, in the authors' opinion they have no real influence on the course of events at the local level. The reason for this is, among other things, the lack of (a) unified representation - common economic self-government. 
